\title{
Multimodal Primary Treatment of Metastatic Prostate Cancer with Androgen Deprivation and Radiation
}

\author{
TIMO JOENSUU ${ }^{1}$, GREETTA JOENSUU ${ }^{1,2^{*}}$, KALEVI KAIREMO ${ }^{1,3^{*}}$, TIMO KILJUNEN ${ }^{1}$, MAIGO RIENER ${ }^{1}$, \\ AILI AALTONEN ${ }^{1}$, MARTTI ALA-OPAS $^{1}$, AKI KANGASMÄKI ${ }^{1}$, TUOMO ALANKO ${ }^{1}$, LAURI TAIPALE $^{1,4}$, \\ PETTERI HERVONEN $^{1,5}$, ANNA BÜTZOW ${ }^{6}$, IRENE VIRGOLINI ${ }^{7}$ and AKSELI HEMMINKI ${ }^{1,4,8}$ \\ ${ }^{1}$ Docrates Cancer Center, Helsinki, Finland ; \\ ${ }^{2}$ Doctoral Programme of Clinical Research, University of Helsinki, Biomedicum Helsinki, Helsinki, Finland; \\ ${ }^{3}$ Department of Nuclear Medicine, University of Texas MD Anderson Cancer Center, Houston, TX, U.S.A.; \\ ${ }^{4}$ Department of Oncology, Helsinki University Central Hospital, Helsinki, Finland; \\ ${ }^{5}$ Department of Oncology, Tampere University Hospital, Tampere, Finland; \\ ${ }^{6}$ United MEDIX Laboratories Ltd., Espoo, Finland; \\ ${ }^{7}$ Department of Nuclear Medicine, Medical University of Innsbruck, Innsbruck, Austria; \\ ${ }^{8}$ Cancer Gene Therapy Group, Faculty of Medicine, University of Helsinki, Helsinki, Finland
}

\begin{abstract}
Aim: We combined anti-androgen therapy with radiotherapy in a first-line setting for metastatic prostate cancer aiming to cause maximal cancer-cell death to delay the emergence of castration-resistant disease. Materials and Methods: In this non-randomized retrospective series of 46 patients, the initial median prostate-specific antigen (PSA) was $98.5 \mu \mathrm{g} / \mathrm{l}$ (range=6.7-15,500), median Gleason score 9 and most men had at least $T_{3} N_{1} M_{1}$ disease. All patients received luteinizing hormone releasing hormone analog or degarelix with bicalutamide. If PSA remained above $1 \mu \mathrm{g} / \mathrm{l}$, docetaxel was initiated. At PSA nadir, all patients received radical radiotherapy of the prostate. Results: The median follow-up time was 4.38 years (range $=0.36-11.24)$. Most radiotherapy-related adverse events were grade 1 and transient. There were no grade 4 events. Overall survival (OS) at 5 years was $81.3 \%$. Conclusion: The feasibility and safety of aggressive multimodality treatment were good resulting in an excellent median $O S$ of 8.35 years.
\end{abstract}

This article is freely accessible online.

*These Authors contributed equally to this study.

Correspondence to: Timo Joensuu, MD, Ph.D., Docrates Cancer Center, Saukonpaadenranta 2, FI-00180 Helsinki, Finland. Tel: +358 505001831, Fax: +358 107732099, e-mail: timo.joensuu@docrates.com

Key Words: Retrospective, non-randomized, experimental approach, metastatic prostate cancer, multimodality, radiotherapy, VMAT, HDR brachytherapy, chemotherapy, hormone therapy, Sm-153, Ra-223.
Androgen deprivation therapy is the only treatment recommended by the U.S. National Comprehensive Cancer Network and Finnish National Current Care Guidelines for primarily metastatic prostate cancer (PCa) $(1,2)$. In 2016 , the European Association of Urology added a recommendation of docetaxel in combination with hormonal therapy as primary treatment of metastatic PCa for patients who are fit enough for chemotherapy (3). Radiotherapy and radiopharmaceuticals, such as samarium-153 $\left({ }^{153} \mathrm{Sm}\right.$ EDTMP) or radium-223 $\left({ }^{223} \mathrm{Ra}\right)$, are typically reserved only for palliation, when bone metastases are widespread.

Hormonal therapies are well-established and initially effective in most patients but the problem is that castrationresistant disease eventually emerges. Approximately 91-93\% of patients with metastatic castration-resistant prostate cancer (CRPC) have bone metastases $(4,5)$. The expected survival has been increasing over the past few years to the current estimate of 3.5 years (6).

Docetaxel was approved for CRPC in 2004 and cabazitaxel for docetaxel-resistant disease in $2010(4,7)$. When metastatic CRPC progresses, and if the prostate has not been treated, the main non-skeletal threat is urinary retention. This situation may require catheterization or, even, renal pyelostomies, leading to poor prognosis and quality of life (8). Other risks include intensive- and poorlymanageable pain, fractures, spinal-cord compression and paraplegia, infections, fatigue, and death.

Prostrate radiotherapy can significantly improve the quality of life and prevent obstructive urinary symptoms, even in the metastatic setting (9). The use of radical doses results in excellent prophylactic and palliative results. The additional combination of irradiation with hormone therapy 
can further prolong the survival of PCa patients with lymph node metastases (10).

Intensity-modulated radiotherapy (IMRT) became available in the late 1990s and volumetric-modulated arc therapy (VMAT) radiotherapy technique in the late 2000s, enabling optimized dose distributions and, especially, reducing normal tissue doses. High-dose radiotherapy combined with effective systemic therapy might minimize the number of PCa cells in the prostate and in pelvic lymph nodes, despite the disease being metastatic. Moreover, the VMAT technique makes it possible to irradiate pelvic-bone metastases, lymph nodes and prostate in tandem and with different doses for each target. The active lesions can be targeted even more precisely when dose planning computer tomography (CT) is registered with magnetic resonance imaging (MRI), ${ }^{18} \mathrm{~F}$-sodium fluoride $\left(\mathrm{Na}^{18} \mathrm{~F}\right), \quad{ }^{18} \mathrm{~F}$-fluoromethylcholine $\quad\left({ }^{18} \mathrm{~F}-\mathrm{FCH}\right)$ and/or ${ }^{68}$ gallium- and prostate-specific membrane antigen - labeled positron emission tomography - CT $\left({ }^{68} \mathrm{Ga}\right.$-PSMA-PET-CT).

Our objective was to use adaptive multimodal treatment in order to kill as many tumor cells as possible, on a body-wide level, in the setting of primarily metastatic PCa. Prostatespecific antigen (PSA) was used as a practical surrogate for good systemic control and for establishing the ideal timing for starting radiotherapy. In addition to radical local/locoregional radiotherapy, we used radiopharmaceuticals on a patient-bypatient basis to achieve systemic irradiation of skeletal metastases.

This is a non-randomized, retrospective register study based on patient records at Docrates Cancer Center, Helsinki, Finland. All patients had newly-diagnosed and previouslyuntreated PCa that was metastasized, at least, into the skeleton.

\section{Materials and Methods}

Analysis of this patient series was authorized by the Finnish National Institute for Health and Welfare, Data Protection Ombudsman, as well as Population Register Centre, and conducted according to the principles of the Declaration of Helsinki. It included 46 consecutive patients who had histologically-confirmed prostate adenocarcinoma with bone metastases (Table I). Another unifying factor for all patients was the same oncologist who gave the primary treatment and provided the contouring and specifications of targets and organs at risk regarding radiotherapy.

Screening. Screening (Table I) was performed with whole body CT, bone scintigraphy and MRI or (from 2010 onwards) PET-CT (Siemens Biograph 6; Siemens Magnetom Espree, Erlangen, Germany) using ${ }^{18} \mathrm{~F}$-choline, ${ }^{18} \mathrm{~F}$-Fluoride or, most recently (from October 2015 ), ${ }^{68} \mathrm{Ga}-$ PSMA. Most of the patients underwent endorectal multiparametric MRI (1.5T; Siemens Magnetom Espree) before diagnostic biopsies.

Systemic therapies. The treatment strategy was the same for every patient in this fairly homogenous patient group: instead of using androgen deprivation alone we strived to use several different treatments to reduce the number of cancer cells in the body as low as possible, prior to initiation of radiation therapy.

All patients underwent castration with luteinizing hormonereleasing hormone (LHRH) analogs or LHRH antagonist as primary treatment. In addition, anti-androgen bicalutamide commenced with a daily dose of $150 \mathrm{mg}$ following a single fraction breast irradiation of $12 \mathrm{~Gy}(6-9 \mathrm{MeV})$ for reduction or prevention of mastodynia and gynecomastia.

Patients underwent PSA measurements once a month and if PSA decrease stopped, they received docetaxel $75 \mathrm{mg} / \mathrm{m}^{2}$ every three weeks or $50 \mathrm{mg} / \mathrm{m}^{2}$ every two weeks $(4,11)$. In Finland, abiraterone (orally $1 \mathrm{~g}$ daily together with $10 \mathrm{mg}$ of prednisolone) became available in 2011 and enzalutamide (orally $160 \mathrm{mg}$ daily) in $2014(12,13)$.

Prior to 2010, docetaxel was the only chemotherapy shown to yield a survival benefit in metastatic CRPC. Therefore, the experimental combination of gemcitabine and oxaliplatin was used in selected patients $(14,15)$. Our practice was to administer gemcitabine $1,000 \mathrm{mg} / \mathrm{m}^{2}$ together with oxaliplatin $85 \mathrm{mg} / \mathrm{m}^{2}$ every two weeks. Following approval, cabazitaxel $25 \mathrm{mg} / \mathrm{m}^{2}$ every 3 weeks was used as second-line chemotherapy (7). All other therapies the patients received are listed in Table II.

Radiation therapy. When PSA nadir was reached, every patient received external beam radiation with radical doses (78 or 80 Gy in 2 Gy fractions) to the prostate. Dose planning CT was registered with MRI, ${ }^{18} \mathrm{~F}$-Choline-, ${ }^{18} \mathrm{~F}$-Fluoride- or ${ }^{68} \mathrm{Ga}$-PSMA-PET-CT in order to contour the target and borders of normal anatomical structures (organs at risk) as precisely as possible. In addition to the prostate, radiotherapy covered bone metastases without significantly increasing the dose of rectum as seen in Figure 1a.

The mean radiation dose to the prostate was $78.2 \mathrm{~Gy}$ in 44 men. Two patients received a combination of 50 Gy VMAT and $2 \times 10$ Gy high-dose-rate (HDR) brachytherapy. All patients received at least 50 Gy in 2 Gy fractions (mean=51) into seminal vesicles; in two patients, the dose was increased up to $79.5 \mathrm{~Gy}$.

Regional, as well as retroperitoneal or para-aortic, lymph nodes were treated with 45-50 Gy, which was escalated to 59.4-76 Gy to PET-CT active metastases (Figure 1b-d). The treatment of bone metastases was tailored: single fractions ranged from 1.8 to 3.5 and total doses from 38.6 to 76.5 Gy depending on the location and number of bone metastases. The total radiation dose of pelvic lymph nodes was at least $45 \mathrm{~Gy}$ given in 25 fractions.

The radiation technique used before 2009 was IMRT, after which the VMAT RapidArc replaced it. The radiation therapy technique used in the treatment of concomitant bone metastases has been presented in detail by Kiljunen et al. (16).

Radiopharmaceuticals. Radiopharmaceuticals were used to treat 32 patients who had relatively large and diffuse bone metastases Table III, in order to decrease the tumor burden and consequently to achieve better disease control. It was noteworthy that bone metastases were active in $\mathrm{Na}^{18} \mathrm{~F}-\mathrm{PET}-\mathrm{CT}$, despite immeasurable PSA, providing the rationale for early ${ }^{223} \mathrm{Ra}$ therapy (Figure 1e). We switched from ${ }^{153} \mathrm{Sm}(1 \mathrm{mCi} / \mathrm{kg})$ to ${ }^{223} \mathrm{Ra}(55 \mathrm{kBq} / \mathrm{kg})$ in February 2013.

Follow-up. Blood parameters were monitored monthly and later once every three or six months. If PSA increase occurred or patients had any possibly cancer-related symptoms, we attempted to localize the relapse by scanning with PET-CT, after which we 
Table I. Baseline characteristics and TNM dissemination. Three patients had urinary retention at baseline.

\begin{tabular}{|c|c|c|}
\hline \multicolumn{3}{|c|}{ Age at diagnosis (years) } \\
\hline \multirow{2}{*}{\multicolumn{2}{|c|}{$\begin{array}{l}\text { Median } \\
\text { Range }\end{array}$}} & 63 \\
\hline & & $39-86$ \\
\hline \multicolumn{3}{|c|}{ Initial prostate-specific antigen (PSA) $(\mu \mathrm{g} / \mathrm{l})$} \\
\hline \multirow{3}{*}{\multicolumn{2}{|c|}{$\begin{array}{l}\text { Median } \\
\text { Range } \\
\text { Mean }\end{array}$}} & 98.5 \\
\hline & & $6.7-15500$ \\
\hline & & 658 \\
\hline \multicolumn{2}{|c|}{ Gleason Score } & $\mathrm{n}$ \\
\hline \multicolumn{2}{|l|}{7} & 7 \\
\hline \multicolumn{2}{|l|}{8} & 14 \\
\hline \multicolumn{2}{|l|}{9} & 20 \\
\hline \multicolumn{2}{|c|}{10} & 5 \\
\hline \multicolumn{2}{|c|}{ Staging } & $\mathrm{n}$ \\
\hline \multirow[t]{5}{*}{$\mathrm{T}$} & 1 & 1 \\
\hline & 2 & 4 \\
\hline & 3 & 21 \\
\hline & $3 b$ & 6 \\
\hline & 4 & 14 \\
\hline \multirow[t]{2}{*}{$\mathrm{N}$} & 0 & 18 \\
\hline & 1 & 28 \\
\hline & 0 & 0 \\
\hline & 1 & 46 \\
\hline \multicolumn{2}{|c|}{ Metastatic sites } & $\mathrm{n}$ \\
\hline \multicolumn{2}{|c|}{ Bones } & 46 \\
\hline \multicolumn{2}{|c|}{ Pelvic lymph nodes } & 24 \\
\hline \multicolumn{2}{|c|}{ Other lymph nodes } & 17 \\
\hline \multicolumn{2}{|c|}{ Lung } & 1 \\
\hline
\end{tabular}

considered if there was a need for new irradiation with VMAT RapidArc. One of our patients received $3 \times 9$ Gy salvage HDR brachytherapy for local relapse.

\section{Results}

All patients presented with aggressive, high-risk, highvolume disease. Initial median PSA was $98.5 \mu \mathrm{g} / 1$ (range=6.7-15,500), mean PSA $658 \mu \mathrm{g} / 1$, median Gleason score 9 and most men had at least $\mathrm{T}_{3} \mathrm{~N}_{1} \mathrm{M}_{1}$ disease (Table I). One patient had $\mathrm{T}_{1}$ classification but his initial PSA was still $1,000 \mu \mathrm{g} / \mathrm{l}$ reflecting very high-volume disease. Altogether, 24 patients had metastases in obturator, parailiac or in presacral lymph nodes, while 17 had metastases disseminated in inguinal, retroperitoneal, mediastinal or supraclavicular lymph nodes. Of 46 patients, 22 achieved PSA $1 \mu \mathrm{g} / 1$ or lower before prostate radiotherapy.
Table II. All given therapies excluding castration, bicalutamide, volumetric-modulated arc therapy (VMAT) radiotherapy and radiopharmaceuticals to 46 patients.

\begin{tabular}{lc}
\hline Therapy & $\mathrm{n}$ \\
\hline Zoledronate, ibandronate or denosumab & 41 \\
Docetaxel & 30 \\
Cabazitaxel & 11 \\
Abiraterone & 24 \\
Enzalutamide & 19 \\
Gemcitabine + oxaliplatin & 8 \\
Syklofosfamide & 2 \\
Doxorubicin & 2 \\
Carboplatin + etoposide & 2 \\
Cetuximab & 1 \\
Vinblastine + estramustine & 1 \\
Vinorelbine & 1 \\
Pebrolizumab in trial & 1 \\
Other: Salvage HDR brachytherapy & 1 \\
\hline
\end{tabular}

HDR, High-density rate. Before VMAT, 13 patients received docetaxel and two patients received abiraterone.

Table III. Description of all 43 radiopharmaceutical treatments given to 32 patients.

\begin{tabular}{lc}
\hline Radiopharmaceutical \pm chemotherapy & $\mathrm{n}$ \\
\hline${ }^{153} \mathrm{Sm}$ alone & 14 \\
${ }^{153} \mathrm{Sm}+$ mitoxantrone & 1 \\
${ }^{153} \mathrm{Sm}+$ mitoxantrone and ${ }^{153} \mathrm{Sm}$ alone & 1 \\
${ }^{153} \mathrm{Sm}+$ mitoxantrone and ${ }^{153} \mathrm{Sm}+$ docetaxel & 2 \\
${ }^{153} \mathrm{Sm}+$ mitoxantrone and ${ }^{223} \mathrm{Ra}$ & 2 \\
${ }^{153} \mathrm{Sm}+$ docetaxel and ${ }^{223} \mathrm{Ra}$ & 1 \\
${ }^{153} \mathrm{Sm}$ and ${ }^{223} \mathrm{Ra}$ & 5 \\
${ }^{223} \mathrm{Ra}$ alone & 5 \\
${ }^{177} \mathrm{Lu}-\mathrm{PSMA}$ & 1 \\
\hline
\end{tabular}

${ }^{153} \mathrm{Sm}$, Samarium-153; ${ }^{223} \mathrm{Ra}$, Radium-223; ${ }^{177} \mathrm{Lu}$, Lutetium-177; PSMA, prostate-specific membrane antigen. Two patients received $153 \mathrm{Sm}$ before VMAT radiotherapy. Mitoxantrone was given $4 \mathrm{mg} / \mathrm{m}^{2} /$ week $\times 6$ and docetaxel $30 \mathrm{mg} / \mathrm{m}^{2} /$ week $\times 4$. One 90 -year-old, WHO 0 patient received ${ }^{177} \mathrm{Lu}-\mathrm{PSMA}$ at Universitätsklinik für Nuklearmedizin, Innsbruck, Austria.

Radiation therapy. All patients received radical radiation doses to the prostate (Table IV). Altogether, 11 patients received irradiation up to the retroperitoneal lymph node region and 24 received additional planning target volumes for their metastases (1-8 metastases per patient) (Table IV, Figure 1b-d). Generally, we followed the recommendations of QUANTEC and RTOG as described recently (16).

Tolerability. Adverse events that occurred during radiotherapy or were present one year after definitive VMAT are presented in Table V (17). Events related to the treatment 
a

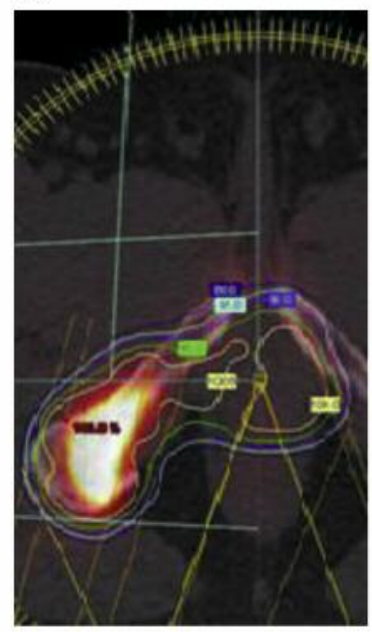

b

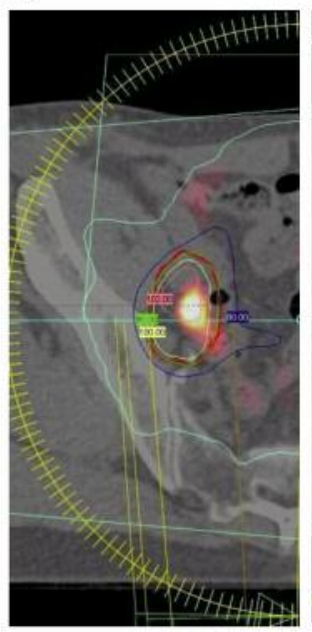

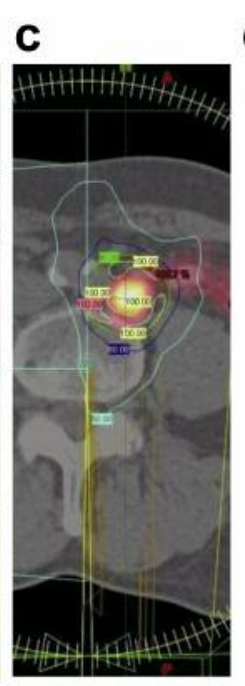
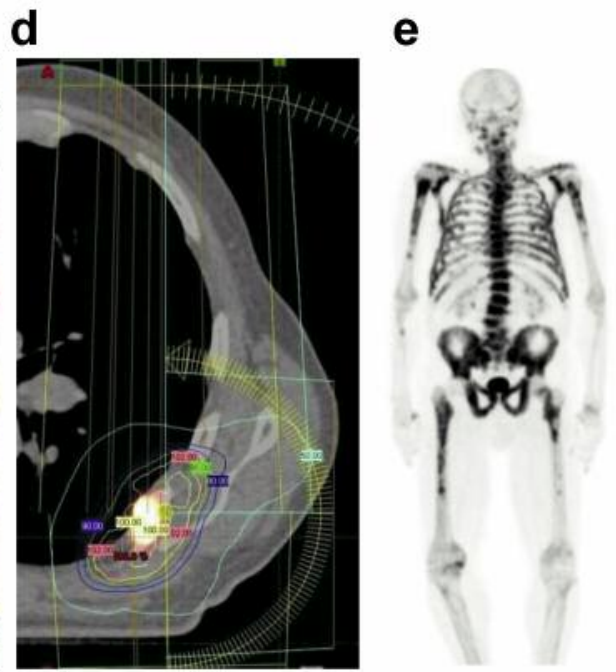

Figure 1. Multimodal treatments for three patients. (a) Dose distribution of VMAT radiotherapy on the level of prostate and ischial tuberosity of a 71-year-old patient with initial PSA $6.78 \mu \mathrm{g} / \mathrm{l}$ while receiving finasteride, Gleason score $8, T_{3} N_{1} M_{1}$. Bone metastasis in right ischial tuberosity treated up to 60/2 Gy (targeted by Nal8 F-PET-CT), prostate 78/2 Gy, seminal vesicles 50/2 Gy and pelvic lymph nodes $45 / 1.8$ Gy. (b-d) 79-yearold, initial PSA $26.7 \mu \mathrm{g} / \mathrm{l}$ while receiving finasteride, Gleason score 9, $T_{3} N_{1} M_{1}$. Radiation doses: prostate $78 / 2 \mathrm{gy}$, seminal vesicles 50/2 Gy, pelvic and retroperitoneal lymph nodes $45 / 1.8 \mathrm{~Gy} .{ }^{18} \mathrm{~F}-\mathrm{FCH}$-PET positive lymph nodes in Figure $1 \mathrm{~b}$ and $1 \mathrm{c}$ treated up to $45 / 1.8 \mathrm{~Gy}+26 / 2 \mathrm{~Gy}$ respectively. The rib in Figure 1d targeted by Na ${ }^{18}$ F-PET-CT treated up to 52.5/3.5 Gy. (e) 74-year-old, initial PSA $236 \mu \mathrm{g} /$, alkaline phosphatase 2,498 U/l, Gleason score $9, T_{3} b N_{1} M_{1} . N a^{18} F-P E T-C T$ showed active uptake, despite earlier castration chemotherapy and radical radiotherapy to the prostate with VMAT radiotherapy and HDR brachytherapy. Therefore, the patient received ${ }^{223}$ Ra for 6 cycles, despite PSA <0.05 $\mu$ g/l.

of metastases did not exceed grade 1. One patient experienced grade 2-3 pollacisuria and nocturia, one had weak urinary stream, three required catheterization for urinary retention and one experienced incontinence. However, the latter patient used high-dose diuretics due to heart problems, which may have contributed. With the benefit of hindsight, we think that radiotherapy could have been better optimized with this patient by using a more complicated dose plan with 4 arcs instead of 2 . One patient experienced transient grade 3 diarrhea, which occurred at the beginning of radiotherapy and resolved before its completion. The main result was that one year after radiation therapy, none of our patients had worse than grade 1 gastrointestinal events and only one patient experienced a grade 2 genitourinary event.

Survival. Eleven patients died from $\mathrm{PCa}$, of whom eight had PSA higher than $1 \mu \mathrm{g} / 1$ (median=3.2 $\mu \mathrm{g} / \mathrm{l}$, range=1.07-104 $\mu \mathrm{g} / \mathrm{l}) \mathrm{just}$ before radical radiotherapy began. One patient died at the age of 90 due to pneumonia, which was related to a traumatic hip fracture. He had immeasurable PSA at the time of his death.

The median follow-up time reached 4.38 years (mean $=4.63$, range $=0.36-11.24)$. At 5 years, progression-free survival (PFS) was 21.6\%. Median PFS was 3.03 years
(Figure 2). Overall survival (OS) was an impressive $81.3 \%$ at 5 years. Median OS was 8.35 years (Figure 3 ).

\section{Discussion}

Patients with metastatic PCa can live up to 15 years, despite large skeletal metastases, if the disease is treated using all different modalities of hormone manipulations, chemotherapies, radiotherapy, radiopharmaceuticals and experimental approaches (18). It is also known that total urinary obstruction, usually caused by locally-progressing CRPC, can be treated with radical doses of radiotherapy (9). Radiotherapy, however, is not generally used when PCa is diagnosed in the metastatic phase.

We hypothesized that it would be useful to prevent urinary retention by using radiotherapy in earlier phases of the disease. Given that the prostate is the source of metastases, we anticipated that local treatment could significantly reduce further seeding and dissemination of the disease. The best timing for radiation therapy might be immediately during the remission, which will be achieved in most cases by castration alone.

Men can live over 10 years when treated with castration alone, although this does not occur in the majority of patients (19). This is unachievable for the most aggressive tumor 


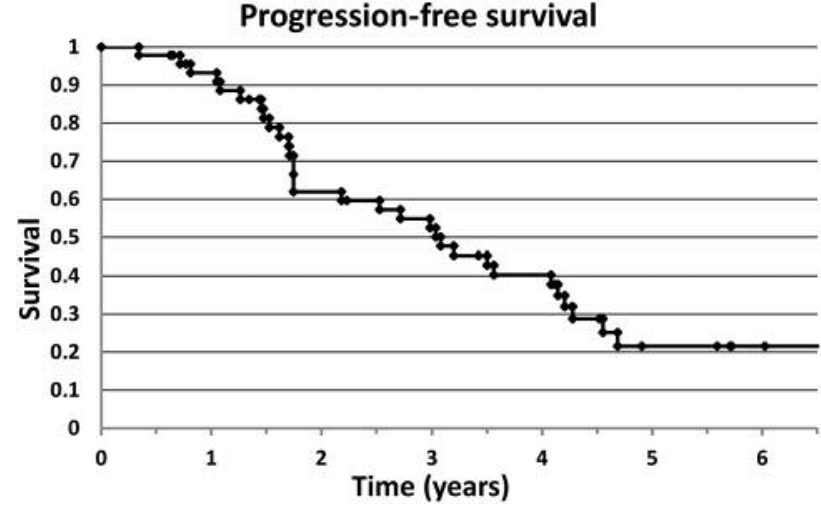

Figure 2. Progression-free survival.

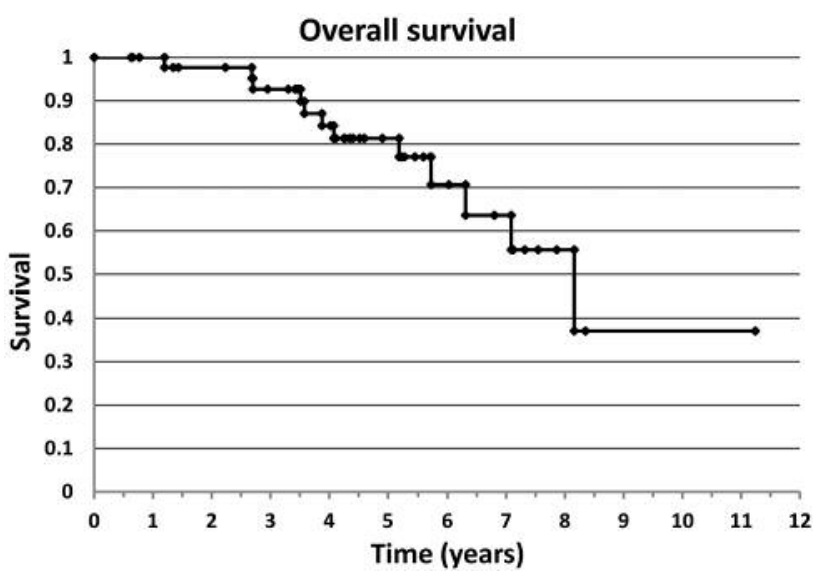

Figure 3. Overall survival. Data collected from the Population Register Centre of Finland.

Table IV. The number of patients $(n)$ with different planning target volume dose prescriptions for primary pelvic radiation therapy.

\begin{tabular}{|c|c|c|c|c|c|c|}
\hline \multirow{3}{*}{ Dose range } & \multicolumn{3}{|c|}{ Prostate cancer radiotherapy prescription } & \multicolumn{3}{|c|}{ Metastatic prostate cancer radiotherapy prescription } \\
\hline & Prostate & Seminal vesicles & $\begin{array}{l}\text { Regional lymph } \\
\text { nodes }\end{array}$ & Bone metastases** & $\begin{array}{l}\text { Lymph node } \\
\text { metastases }\end{array}$ & $\begin{array}{c}\text { Retroperitoneal/ } \\
\text { para-aortic lymph nodes }\end{array}$ \\
\hline & $\mathrm{n}($ mean dose $[\mathrm{Gy}])$ & $\mathrm{n}($ mean dose $[\mathrm{Gy}])$ & $\mathrm{n}($ mean dose $[\mathrm{Gy}])$ & $\mathrm{n}($ mean dose $[\mathrm{Gy}])$ & $\mathrm{n}($ mean dose $[\mathrm{Gy}])$ & $\mathrm{n}($ mean dose $[\mathrm{Gy}])$ \\
\hline $76-80 \mathrm{~Gy}$ & $44(78.2)$ & $2(79.5)$ & & $3(76.5)$ & $1(76.0)$ & \\
\hline $60-75$ Gy & & & & $9(66.0)$ & $2(66.7)$ & \\
\hline $50-59$ Gy & $2(50.0 *)$ & $44(51.0)$ & $7(50.4)$ & $2(50.1)$ & $1(59.4)$ & $6(50.3)$ \\
\hline 40-49 Gy & & & $39(45.0)$ & $8(43.0)$ & & $5(45.0)$ \\
\hline 30-39 Gy & & & & $1(38.6)$ & & \\
\hline
\end{tabular}

*High-density-rate (HDR) brachytherapy booster $2 \times 10$ Gy after the external beam radiation therapy. 2 Gy/fr equivalent total dose $>116$ Gy $(\alpha / \beta=1.5 \mathrm{~Gy})$. ${ }^{* *}$ Fraction sizes range between $1.8 \mathrm{~Gy}$ and $3.5 \mathrm{~Gy}$. Total dose calculated as $2 \mathrm{~Gy} / \mathrm{fr}$ equivalent dose $(\alpha / \beta=1.5 \mathrm{~Gy})$.

types and in patients with high tumor volume, in particular. The response to castration may be lost within a couple of months, as seen in 13 patients in our practice (28.2\%). In these cases, we immediately started docetaxel. The criterion for docetaxel initiation was that either PSA started increasing or it stopped decreasing.

In maximal androgen blockade studies, bicalutamide has been typically used at $50 \mathrm{mg}$, with the rationale being that patients' testosterone levels are low due to castration. Bicalutamide, however, prevents the effects of testosterone, not by binding to testosterone but by blocking its effect on androgen receptors that are numerous, despite low testosterone levels, suggesting that low dose may be suboptimal.

Japanese researchers showed that a higher dose of bicalutamide $(80 \mathrm{mg})$, in combination with castration, significantly improved the survival of metastatic PCa without impairing quality of life $(20,21)$. Recent studies of abiraterone and enzalutamide showed efficacy even in the castration-resistant phase, confirming that total eradication of the testosterone effect is worthwhile $(12,13)$. Therefore, we combined bicalutamide $150 \mathrm{mg}$ and LHRH analogs or degarelix as first-line therapy.

VMAT enables concomitant radiotherapy of PCa and pelvic-bone metastases (16). This technique can be optimized by contouring targets with PET-CT. In the pelvis, the rationale for treatment of individual metastases at an early phase, together with the prostate, relates to the feasibility of covering of all lesions simultaneously. If radiotherapy is given just to the prostate and pelvic lymph nodes, it is more dose-limiting to treat other pelvic metastases later. Our experience suggests that long-term remission of pelvic lesions can be achieved with this 
Table V. Adverse events recorded during volumetric-modulated arc therapy (VMAT) radiotherapy or one year after graded by common terminology criteria for adverse events (17).

\begin{tabular}{|c|c|c|c|c|c|c|c|c|c|c|}
\hline & \multicolumn{6}{|c|}{ During radiotherapy } & \multicolumn{4}{|c|}{ One year after radiotherapy } \\
\hline & \multicolumn{10}{|c|}{ Grade } \\
\hline & 0 & 1 & 2 & 3 & 4 & 0 & 1 & 2 & 3 & 4 \\
\hline Adverse events related to urination & 5 & 35 & 2 & 4 & 0 & 26 & 14 & 1 & 1 & 0 \\
\hline Adverse events related to bowel function & 14 & 31 & 0 & 1 & 0 & 37 & 5 & 0 & 0 & 0 \\
\hline Other* & 0 & 3 & 0 & 0 & 0 & 0 & 0 & 0 & 0 & 0 \\
\hline
\end{tabular}

*Esophagitis related to radiotherapy of mediastinal lymph nodes. Follow-up was less than one year for four patients. Erectile function was not recorded since all men were castrated.

approach. Further rationale for the treatment of individual PET-active metastases is provided by Gundem et al. who suggested that metastases can seed new metastases (22). If oligometastases could be controlled, dissemination might decrease.

To assess the feasibility of combining radiotherapy with castration, we assessed its tolerability. Some of our patients (28.2\%) received docetaxel before VMAT radiotherapy, potentially increasing overall toxicity. No grade 4 or 5 adverse events were seen, however. The number of grade 3 events was low and all were reversible. All patients had recovered from adverse events by one year. Good tolerability of the combination of castration and irradiation was not surprising, since this is a routine approach in local high-risk $\mathrm{PCa}$ (23); however, here, we confirmed its safety in the metastatic setting also.

In 2004, docetaxel was demonstrated to provide a survival benefit in CRPC (4). In the STAMPEDE trial, docetaxeltreated patients had $50 \%$ survival at 5 years compared to $39 \%$ in the control group receiving the standard of care (androgen deprivation therapy) alone (6). In CHARTEED, the median OS was 57.6 months with androgen deprivation therapy combined to six cycles of docetaxel compared to 44 months with androgen deprivation therapy alone (24).

All PCa patients are not alike. Hinting at the presence of relevant subgroups, PSA decreased rapidly in half of the men reported here, while the other half needed chemotherapy to reach PSA nadir. Of note, Tarish et al. reported that castration mediates radiosensitization by impairing DNAdouble-strand repair (25).

In 2005, Loberg et al. reported that radiopharmaceuticals can improve survival and be integrated within chemotherapy regimens, which Fizazi et al. confirmed with ${ }^{153} \mathrm{Sm}$ and docetaxel $(26,27)$. The seminal trial in this area was ALSYMPCA, featuring ${ }^{223} \mathrm{Ra}$, which showed a clear survival benefit (28). Our practice is to give ${ }^{153} \mathrm{Sm}$ or $223 \mathrm{Ra}$ as early as possible with the assumption that treatment benefits are greater when tumor load is low.
The main concern related to early treatment with marrow toxic agents, such as radiopharmaceuticals and chemotherapies, is the damage they can cause to hematopoiesis, thus potentially limiting the usability of subsequent regimens. Approximately $65 \%$ of our patients received docetaxel and $24 \%$ received cabazitaxel. In addition, we used several less routine chemotherapies. At the time of diagnosis of metastatic disease, $28 \%$ of our patients were 70 years or older, which forced us to be cautious with each therapy option available. Two patients were cytopenic when they died. It is possible that protracted treatment caused grade 3 leucocytopenia for one and grade 4 leucocytopenia and thrombocytopenia in the other. However, both patients had massive PCa progression in the bone marrow prior to death, which was probably the main cause of cytopenia. These patients survived 7.1 and 8.1 years, respectively.

The OS in this patient series was $81 \%$ at 5 years and median survival was 8.1 years. Both figures compare favorably to concurrent series reported for the same group of high-risk patients with poor prognosis. In both CHARTEED and STAMPEDE studies, the OS of patients with metastatic PCa was about $50 \%$ at 5 years $(6,24)$. Most recently, Rusthoven et al. retrospectively analyzed the impact of radiation combined to androgen deprivation in previouslyuntreated metastatic PCa compared to androgen deprivation alone (29). Median OS was 4.6 years and 5-year OS 49\%. The main difference compared to our approach appeared to be that we also irradiated bone oligometastases and patients received radiopharmaceuticals if they had widely disseminated bone metastases. In general, the practice of irradiation of oligometastases seems to be increasing in popularity (30).

A common criticism of retrospective series relates to selection bias. To avoid this caveat, the patients reported here are consecutive patients. All of them had stage 4 disease. The initial PSA distribution was quite typical: $19.6 \%$ had initial PSA $\leq 20 \mu \mathrm{g} / \mathrm{l} ; 32.6 \%$ had PSA $>20 \mu \mathrm{g} / \mathrm{l}$ but $\leq 100 \mu \mathrm{g} / \mathrm{l}$; $28.3 \%$ had PSA $>100 \mu \mathrm{g} / \mathrm{l}$ but $\leq 500 \mu \mathrm{g} / \mathrm{l}$; and $19.6 \%$ had PSA $>500 \mu \mathrm{g} / 1$. Even the age distribution was representative 
a

\section{Endorectal mutliparametric MRI \\ Biopsies + laboratorium tests \\ ${ }^{68} \mathrm{Ga}-\mathrm{PSMA}-$ or ${ }^{18} \mathrm{~F}-\mathrm{FCH}-+/-\mathrm{Na}{ }^{18} \mathrm{~F}$-PET-CT \\ Breast irradiation $12 \mathrm{~Gy}(6-9 \mathrm{MeV})$}

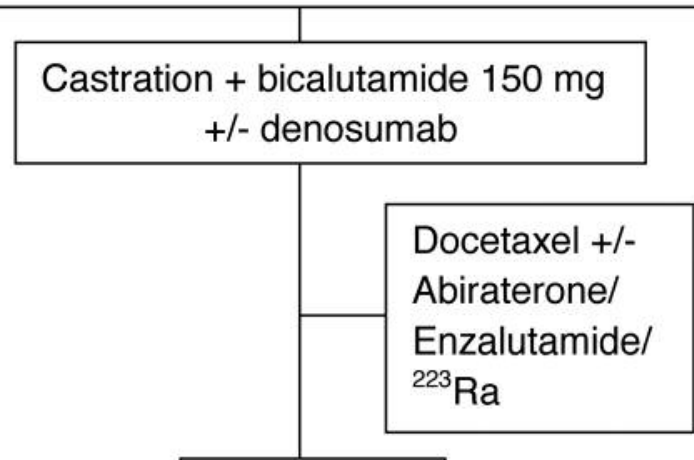

$\mathrm{PSA} \leq 1 \mu \mathrm{g} / \mathrm{l}$

\section{VMAT RapidArc radiotherapy +/- HDR brachytherapy}

${ }^{223} \mathrm{Ra} \times 6$ if

bone metastases active in $\mathrm{Na}^{18} \mathrm{~F}$-PET-CT and no previous ${ }^{223} \mathrm{Ra}$-treatment

Maintenance therapy b

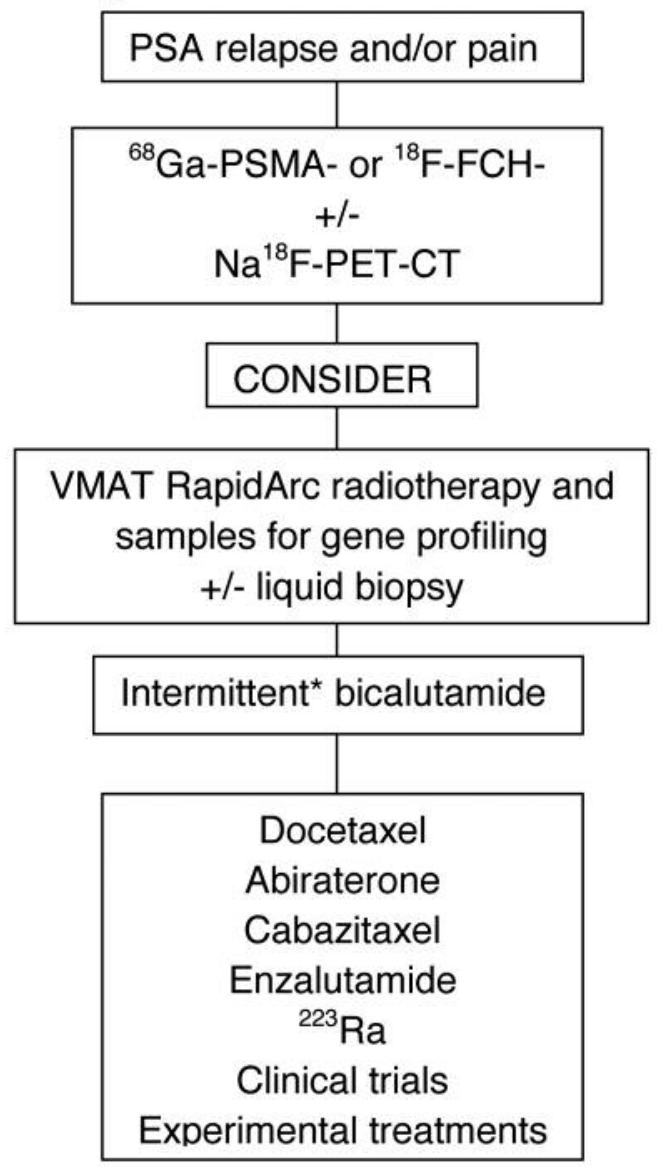

Figure 4. Algorithms for primarily metastatic prostate cancer. (a) Algorithm for diagnostic and treatment procedures in primarily metastatic prostate cancer. (b) Algorithm for follow-up and therapy options in possible relapse of primarily metastatic prostate cancer. *Intermittent: 6 months on therapy, 6 months on pause; only if PSA level is low and active cancer cells are not visible in PET-CT or in other studies. MRI, Magnetic resonance imaging; ${ }^{68} \mathrm{Ga}$-PSMA, Gallium-68-prostate-specific membrane antigen; ${ }^{18} \mathrm{~F}$-FCH, ${ }^{18} \mathrm{~F}$-fluoromethylcholine; $\mathrm{Na}^{18},{ }^{18} \mathrm{~F}$-sodium fluoride; PET, positron emission tomography; CT, computer tomography; ${ }^{223}$ Ra, Radium-223; VMAT, volumetric-modulated arc therapy; HDR, high-density rate.

of PCa patients. All patients were treated according to the same principles, although scheduling and many details were adjusted individually in an adaptive manner.

The obvious weakness of any retrospective analysis is the fact that it is not prospective and randomized. However many treatment innovations are first used in small patient series, prior to rigorous analysis in controlled trials. We feel our results are promising enough to take the approach forward into randomized trials (Figure $4 a, b$ ).

In conclusion, multimodal primary treatment of metastatic prostate cancer with both androgen deprivation and radiation is demonstrated to be potentially feasible in the patient series reported here. Impressive OS data encourages extension of this approach into clinical trials.

\section{Conflicts of Interest}

T.J. is a founder of and shareholder in Docrates Cancer Center. T.H. has received travel support from MSD Finland, Sanofi, Eli Lilly, Janssen and Merck. T.H. has received lecture fee from Bayer. A.H. is shareholder in Targovax ASA. A.H. is employee and shareholder in TILT Biotherapeutics Ltd. and Aeruginosa Oy. A.H. has received travel support from BMS and LeoPharma. A.H. acts as consultant for Amgen Inc. A.K. is shareholder in Docrates Cancer Center.

\section{Acknowledgements}

A.H. is Jane and Aatos Erkko Professor of Oncology at the University of Helsinki. 


\section{References}

1 Mohler J, Armstrong A, Bahnson R, D'Amico A, Davis B, Eastham J, Enke C, Farrington T, Higano C, Horwitz EM, Hurwitz M, Kane C, Kawachi M, Kuettel M, Lee R, Meeks J, Penson D, Plimack E, Pow-Sang JM, Raben D, Richey S, Roach M, Rosenfeld S, Schaeffer E, Skolarus T, Small E, Sonpavde G, Srinivas S, Strope S and Tward J: National Comprehensive Cancer Network. Clinical Practice Guidelines in Oncology. Prostate Cancer, Version 3, 2016. https://www.nccn.org/ professionals/physician_gls/pdf/prostate.pdf. Accessed September 12, 2016.

2 Aaltomaa S, Jousilahti P, Kataja V, Korpela M, Kujala P, Laato M, Lindholm P, Matikainen M, Rannikko A, Sipilä R and Tammela T: Finnish Current Care Guideline. Prostate Cancer, 2015. http://www.kaypahoito.fi/web/kh/suositukset/suositus? id=hoi11060\#NaN. Accessed September 12, 2016.

3 Mottet N, Bellmunt J, Briers E, Bolla M, Cornford P, De Santis M, Henry A, Joniau S, Lam T, Mason MD, Matveev V, van der Poel H, van der Kwast TH, Rouvière $\mathrm{O}$ and Wiegel T: European Association of Urology, European Society for Radiotherapy and Oncology, International Society of Geriatric Oncology. Guidelines on Prostate Cancer. 2016. http://uroweb.org/wpcontent/uploads/EAU-Guidelines-Prostate-Cancer-2016.pdf. Accessed September 12, 2016.

4 Tannock IF, de Wit R, Berry WR, Horti J, Pluzanska A, Chi KN, Oudard S, Theodore C, James ND, Turesson I, Rosenthal MA, Eisenberger MA and TAX 327 Investigators: Docetaxel plus prednisone or mitoxantrone plus prednisone for advanced prostate cancer. N Engl J Med 351: 1502-1512, 2004.

5 Oudard S, Banu E, Beuzeboc P, Voog E, Dourthe LM, HardyBessard AC, Linassier C, Scotte F, Banu A, Coscas Y, Guinet F, Poupon MF and Andrieu JM: Multicenter randomized phase II study of two schedules of docetaxel, estramustine, and prednisone versus mitoxantrone plus prednisone in patients with metastatic hormone-refractory prostate cancer. J Clin Oncol 23: 3343-3351, 2005.

6 James ND, Sydes MR, Clarke NW, Mason MD, Dearnaley DP, Spears MR, Ritchie AW, Parker CC, Russell JM, Attard G, de Bono J, Cross W, Jones RJ, Thalmann G, Amos C, Matheson D, Millman R, Alzouebi M, Beesley S, Birtle AJ, Brock S, Cathomas R, Chakraborti P, Chowdhury S, Cook A, Elliott T, Gale J, Gibbs S, Graham JD, Hetherington J, Hughes R, Laing R, McKinna F, McLaren DB, O’Sullivan JM, Parikh O, Peedell C, Protheroe A, Robinson AJ, Srihari N, Srinivasan R, Staffurth J, Sundar S, Tolan S, Tsang D, Wagstaff J, Parmar MK and STAMPEDE investigators: Addition of docetaxel, zoledronic acid, or both to first-line long-term hormone therapy in prostate cancer (STAMPEDE): Survival results from an adaptive, multiarm, multistage, platform randomised controlled trial. Lancet 387: 1163-1177, 2016.

7 de Bono JS, Oudard S, Ozguroglu M, Hansen S, Machiels JP, Kocak I, Gravis G, Bodrogi I, Mackenzie MJ, Shen L, Roessner M, Gupta S, Sartor AO and TROPIC Investigators: Prednisone plus cabazitaxel or mitoxantrone for metastatic castration-resistant prostate cancer progressing after docetaxel treatment: A randomised open-label trial. Lancet 376: 11471154, 2010.

8 Oefelein MG: Prognostic significance of obstructive uropathy in advanced prostate cancer. Urology 63: 1117-1121, 2004.
9 Perez CA, Cosmatos D, Garcia DM, Eisbruch A and Poulter CA: Irradiation in relapsing carcinoma of the prostate. Cancer 71 : 1110-1122, 1993.

10 Briganti A, Karnes RJ, Da Pozzo LF, Cozzarini C, Capitanio U, Gallina A, Suardi N, Bianchi M, Tutolo M, Salonia A, Di Muzio N, Rigatti P, Montorsi F and Blute M: Combination of adjuvant hormonal and radiation therapy significantly prolongs survival of patients with pT2-4 pN+ prostate cancer: Results of a matched analysis. Eur Urol 59: 832-840, 2011.

11 Kellokumpu-Lehtinen PL, Harmenberg U, Joensuu T, McDermott R, Hervonen P, Ginman C, Luukkaa M, Nyandoto P, Hemminki A, Nilsson S, McCaffrey J, Asola R, TurpeenniemiHujanen T, Laestadius F, Tasmuth T, Sandberg K, Keane M, Lehtinen I, Luukkaala T, Joensuu H and PROSTY study group: 2-Weekly versus 3-weekly docetaxel to treat castration-resistant advanced prostate cancer: a randomised, phase 3 trial. Lancet Oncol 14: 117-124, 2013.

12 de Bono JS, Logothetis CJ, Molina A, Fizazi K, North S, Chu L, Chi KN, Jones RJ, Goodman OB,Jr, Saad F, Staffurth JN, Mainwaring P, Harland S, Flaig TW, Hutson TE, Cheng T, Patterson H, Hainsworth JD, Ryan CJ, Sternberg CN, Ellard SL, Flechon A, Saleh M, Scholz M, Efstathiou E, Zivi A, Bianchini D, Loriot Y, Chieffo N, Kheoh T, Haqq CM, Scher HI and COU-AA-301 Investigators: Abiraterone and increased survival in metastatic prostate cancer. N Engl J Med 364: 1995-2005, 2011.

13 Beer TM, Armstrong AJ, Rathkopf DE, Loriot Y, Sternberg CN, Higano CS, Iversen P, Bhattacharya S, Carles J, Chowdhury S, Davis ID, de Bono JS, Evans CP, Fizazi K, Joshua AM, Kim CS, Kimura G, Mainwaring P, Mansbach H, Miller K, Noonberg SB, Perabo F, Phung D, Saad F, Scher HI, Taplin ME, Venner PM, Tombal $\mathrm{B}$ and PREVAIL Investigators: Enzalutamide in metastatic prostate cancer before chemotherapy. N Engl J Med 371: 424-433, 2014.

14 Muenchen HJ, Quigley MM, Pilat MJ, Lehr JE, Brumfield SK, Mahoney $\mathrm{M}$ and Pienta KJ: The study of gemcitabine in combination with other chemotherapeutic agents as an effective treatment for prostate cancer. Anticancer Res 20: 735-740, 2000.

15 Droz JP, Muracciole X, Mottet N, Ould Kaci M, Vannetzel JM, Albin N, Culine S, Rodier JM, Misset JL, Mackenzie S, Cvitkovic $\mathrm{E}$ and Benoit G: Phase II study of oxaliplatin versus oxaliplatin combined with infusional 5-fluorouracil in hormone refractory metastatic prostate cancer patients. Ann Oncol 14: 1291-1298, 2003.

16 Kiljunen T, Kangasmaki A, Aaltonen A, Kairemo K, Partanen K, Joensuu G, Alanko T, Vaalavirta L and Joensuu T: VMAT technique enables concomitant radiotherapy of prostate cancer and pelvic bone metastases. Acta Oncol 54: 847-853, 2015.

17 U.S. Department of Health and Human Services, National Institutes of Health, National Cancer Institute: Common Terminology Criteria for Adverse Events. Version 4.03. 2010. http://evs.nci.nih.gov/ftp1/CTCAE/CTCAE_4.03_2010-0614_QuickReference_8.5x11.pdf. Accessed September 12, 2016.

18 Joensuu TK: Renal toxicity following zoledronic acid reversed with ibandronate in a prostate cancer patient with bone metastases. Urol Int 80: 448-450, 2008.

19 Huggins C and Hodges CV: Studies on prostatic cancer. I. The effect of castration, of estrogen and of androgen injection on serum phosphatases in metastatic carcinoma of the prostate. 1941. J Urol 167: 948-51; discussion 952, 2002. 
20 Akaza H, Hinotsu S, Usami M, Arai Y, Kanetake H, Naito S, Hirao Y and Study Group for the Combined Androgen Blockade Therapy of Prostate Cancer: Combined androgen blockade with bicalutamide for advanced prostate cancer: Long-term follow-up of a phase 3, double-blind, randomized study for survival. Cancer 115: 3437-3445, 2009.

21 Arai Y, Akaza H, Deguchi T, Fujisawa M, Hayashi M, Hirao Y, Kanetake H, Naito S, Namiki M, Tachibana M, Usami M and Ohashi Y: Evaluation of quality of life in patients with previously untreated advanced prostate cancer receiving maximum androgen blockade therapy or LHRHa monotherapy: A multicenter, randomized, double-blind, comparative study. J Cancer Res Clin Oncol 134: 1385-1396, 2008.

22 Gundem G, Van Loo P, Kremeyer B, Alexandrov LB, Tubio JM, Papaemmanuil E, Brewer DS, Kallio HM, Hognas G, Annala M, Kivinummi K, Goody V, Latimer C, O'Meara S, Dawson KJ, Isaacs W, Emmert-Buck MR, Nykter M, Foster C, Kote-Jarai Z, Easton D, Whitaker HC, ICGC Prostate UK Group, Neal DE, Cooper CS, Eeles RA, Visakorpi T, Campbell PJ, McDermott U, Wedge DC and Bova GS: The evolutionary history of lethal metastatic prostate cancer. Nature 520: 353-357, 2015

23 Bolla M, Gonzalez D, Warde P, Dubois JB, Mirimanoff RO, Storme G, Bernier J, Kuten A, Sternberg C, Gil T, Collette L and Pierart M: Improved survival in patients with locally advanced prostate cancer treated with radiotherapy and goserelin. N Engl J Med 337: 295-300, 1997.

24 Sweeney CJ, Chen YH, Carducci M, Liu G, Jarrard DF, Eisenberger M, Wong YN, Hahn N, Kohli M, Cooney MM, Dreicer R, Vogelzang NJ, Picus J, Shevrin D, Hussain M, Garcia JA and DiPaola RS: Chemohormonal therapy in metastatic hormonesensitive prostate cancer. N Engl J Med 373: 737-746, 2015.

25 Tarish FL, Schultz N, Tanoglidi A, Hamberg H, Letocha H, Karaszi K, Hamdy FC, Granfors T and Helleday T: Castration radiosensitizes prostate cancer tissue by impairing DNA doublestrand break repair. Sci Transl Med 7: 312re11, 2015.
26 Loberg RD, Logothetis CJ, Keller ET and Pienta KJ: Pathogenesis and treatment of prostate cancer bone metastases: Targeting the lethal phenotype. J Clin Oncol 23: 8232-8241, 2005.

27 Fizazi K, Beuzeboc P, Lumbroso J, Haddad V, Massard C, Gross-Goupil M, Di Palma M, Escudier B, Theodore C, Loriot Y, Tournay E, Bouzy J and Laplanche A: Phase II trial of consolidation docetaxel and samarium-153 in patients with bone metastases from castration-resistant prostate cancer. J Clin Oncol 27: 2429-2435, 2009.

28 Parker C, Nilsson S, Heinrich D, Helle SI, O’Sullivan JM, Fossa SD, Chodacki A, Wiechno P, Logue J, Seke M, Widmark A, Johannessen DC, Hoskin P, Bottomley D, James ND, Solberg A, Syndikus I, Kliment J, Wedel S, Boehmer S, Dall'Oglio M, Franzen L, Coleman R, Vogelzang NJ, O'Bryan-Tear CG, Staudacher K, Garcia-Vargas J, Shan M, Bruland OS, Sartor O and ALSYMPCA Investigators: Alpha emitter radium-223 and survival in metastatic prostate cancer. N Engl J Med 369: 213223, 2013.

29 Rusthoven CG, Jones BL, Flaig TW, Crawford ED, Koshy M, Sher DJ, Mahmood U, Chen RC, Chapin BF, Kavanagh BD and Pugh TJ: Improved survival with prostate radiation in addition to androgen deprivation therapy for men with newly diagnosed metastatic prostate cancer. J Clin Oncol 34: 2835-2842, 2016.

30 Anonymous: Local Consolidative Therapy for Oligometastatic Non-Small Cell Lung Cancer. OncoLog 61(7): 5, 2016.

Received September 13, 2016

Revised September 21, 2016

Accepted September 22, 2016 